\title{
Cloning and expression of an endo-1,4- $\beta-$-xylanase from the coffee berry borer, Hypothenemus hampei
}

Beatriz Padilla-Hurtado ${ }^{1 \dagger}$, Claudia Flórez-Ramos ${ }^{2 \dagger}$, Carolina Aguilera-Gálvez ${ }^{1}$, Jefferson Medina-Olaya ${ }^{1}$, Andrés Ramírez-Sanjuan ${ }^{1}$, José Rubio-Gómez ${ }^{1}$ and Ricardo Acuña-Zornosa ${ }^{1 *}$

\begin{abstract}
Background: The coffee berry borer, Hypothenemus hampei, reproduces and feeds exclusively on the mature endosperm of the coffee seed, which has a cell wall composed mainly of a heterogeneous mixture of hemicellulose polysaccharides, including arabinoxylans. Xylanases are digestive enzymes responsible for the degradation of xylan based polymers, hydrolyzing them into smaller molecules that are easier to assimilate by insects. We report the cloning, expression and enzymatic characterization of a xylanase gene that was identified in the digestive tract of the coffee berry borer.

Methods: The complete DNA sequence encoding a H. hampei xylanase (HhXyl) was obtained using a genome walking technique in a CDNA library derived from the borer digestive tract. The XIP-I gene was amplified from wheat (Triticum aestivum variety Soisson). A Pichia pastoris expression system was used to express the recombinant form of these enzymes. The xylanase activity and XIP-I inhibitory activity was quantified by the 3,5-dinitrosalicylic (DNS). The biological effects of XIP-I on borer individuals were evaluated by providing an artificial diet enriched with the recombinant XIP-I protein to the insects.
\end{abstract}

Results: The borer xylanase sequence contains a 951 bp open reading frame that is predicted to encode a 317amino acid protein, with an estimated molecular weight of $34.92 \mathrm{kDa}$ and a pl of 4.84 . Bioinformatic analysis revealed that HhXyl exhibits high sequence homology with endo- $\beta$-D-xylanases of Streptomyces bingchenggensis from glycosyl hydrolase 10 (GH10). The recombinant xylanase showed maximal activity at pH 5.5 and $37^{\circ} \mathrm{C}$. XIP-I expressed as a recombinant protein inhibited HhXyl activity in vitro and caused individual $H$. hampei mortality in bioassays when included as a supplement in artificial diets.

Conclusion: A xylanase from the digestive tract of the coffee berry borer was identified and functionally characterized. A xylanase inhibitor protein, XIP-I, from wheat was shown to be a potent inhibitor of this xylanase, suggesting that its deployment has potential as a strategy to control coffee berry borer colonization of coffee plants.

\section{Background}

The coffee berry borer, Hypothenemus hampei (Ferrari) (Coleoptera: Curculionidae), is the most important pest of coffee crops worldwide. It causes annual economic losses close to $\$ 500$ million due to loss of seed weight and premature fall of the bean [1]. In Colombia, it is

\footnotetext{
* Correspondence: Ricardo.Acuna@cafedecolombia.com

† Contributed equally

'Disciplina de Mejoramiento Genético, Centro Nacional de Investigaciones de Café (CENICAFE), Planalto, Km 4 vía antigua Chinchiná-Manizales,

Chinchiná, Colombia

Full list of author information is available at the end of the article
}

estimated that borer infestation affects 800,000 acres, affecting the assets of more than half a million coffee growers [2].

The insect feeds exclusively on the fruit and reproduces inside the coffee seed. Carbohydrates, in the form of polysaccharides and free sugars, comprise $50 \%$ of the dry weight of the mature seed of the coffee bean. The polysaccharides include galactomannans $(25 \%)$, arabinogalactans (17\%) and cellulose (8\%) [3]. However, other polysaccharides are likely present, including xyloglucan

\section{Biomed Central}


and arabinoxylan, and indeed, acid hydrolysis of seed carbohydrates releases small amounts of xylose [4].

In order to degrade these polysaccharides, the coffee berry borer would need to secrete a range of glycosyl hydrolases (GHs) into its digestive system. Here we report the first characterization of an endo- $\beta-1,4$-xylanase (HhXyl) from the digestive tract of the coffee berry borer. Endo- $\beta-1,4$-xylanases (EC 3.2.1.8) catalyze the hydrolysis of the $\beta-1,4$-xylosidic bonds in the backbone of xylan based polymers [5]. Most of these enzymes are classified in $\mathrm{GH}$ families 10 and 11 based on similarities in the amino acid sequences, catalytic domains, protein folds and overall architecture [6]. Recently, the study of xylanolytic enzymes has been an area of great interest due to their numerous industrial applications $[7,8]$ and their roles as pathogenicity factors in plant pathogenic microbes [9].

The complete $H h X y l$ transcript sequence was determined from a digestive tract cDNA library, and its homology with endo- $\beta-1,4$-xylanase genes from bacteria of the genus Streptomyces was established. Recombinant HhXyl protein was expressed in a Pichia pastoris system to analyze its enzymatic activity. In addition a xylanase inhibitor protein (XIP-I) from wheat (Triticum aestivum variety Soisson) that inhibits endoxylanases, was cloned and similarly expressed [10]. XIP-I inhibits the microbial GH10 and GH11 families of xylanases in a competitive manner [11] as well as two $\alpha$-amylases from barley [12]. The inhibitory activity of recombinant XIP-I against the borer xylanase was evaluated in biochemical and biological assays.

Given their functions as digestive enzymes, the identification and biochemical characterization of glycolytic enzymes in $H$. hampei represents an important step in designing strategies to improve resistance against the insect. Specific protein inhibitors of these enzymes are sought for use in biotechnological strategies and to generate coffee plants that are resistant to this pest.

\section{Results and Discussion}

\section{Isolation and cloning of the xylanase gene from the coffee berry borer}

Of 3,070 sequenced clones in a cDNA library created from the digestive tracts of coffee berry borers, 1,252 unique sequences were obtained. Based on a BLASTX analysis, 124 Expressed Sequence Taq (ESTs) had high homology $\left(E>10^{-4}\right)$ with corresponding sequences of proteins with known catalytic activity. Among the ESTs with putative functional annotations, 5 ESTs were found to be related to digestive proteins, one of which was classified as a putative endo-1,4- $\beta$-xylanase. Based on this EST sequence, a corresponding open reading frame of 951 bp was identified using a genome walking strategy and designated HhXyl [GenBank: HM991729]. This sequence is predicted to encode a 317-amino acid prot ein with an estimated molecular weight of $34.92 \mathrm{kDa}$ and a $\mathrm{pI}$ of 4.84. Sequence analysis using the SignalP 3.0 program [13] indicated that HhXyl is a secreted protein with a peptidase recognition site between the amino acids His16 and Leu17. After removal of the signal peptide, the mature HhXyl is predicted to be a 300 -amino acid protein with a molecular weight of $33.5 \mathrm{kDa}$ and a pI of 4.63. BLAST analysis of the protein showed that HhXyl contains a putative domain between Leu17 and Leu313 (pfam00331) that is conserved in GH10 proteins, which typically have a molecular weight of $\geq 30 \mathrm{kDa}$ and low pI [14]. In terms of substrate specificity, GH10 endoxylanases are generally less selective than those from GH11, but GH10 enzymes can hydrolyze polysaccharides that are more complex [15]. The alignment of the deduced amino acid sequence of HhXyl is shown in Figure 1, together with other GH10 endoxylanases. The functional domain of this family is highly conserved among xylanases of different species, as are the locations of residues Glu138 (acid/base catalyst) and Glu184 (catalytic nucleophile), which play essential roles in the enzymatic reaction $[9,16]$. The greatest identity among sequences (54\%) was obtained by comparing the sequence of HhXyl with the sequences of a $\beta-1,4$-xylanases of Streptomyces bingchenggensis [GenBank: ADI10429] and S. avermitilis [GenBank: NP_826161]. HhXyl showed amino acid sequence identities of $48 \%$, $49 \%, 52 \%$ with the sequences of $\beta-1,4$-xylanases from $S$. megasporus [GenBank:ADE37527.1], Catenulispora acidiphila [GenBank:YP_003115119.1] and S. scabiei [GenBank:YP_003489277.1] respectively (Figure 1).

\section{Characterization of the HhXyl xylanase from coffee berry borer}

The coding sequences of $H h X y l$ and the xylanase inhibitor protein XIP-I from T. aestivum were cloned, without their respective signal peptides, into the pPICZ $\alpha \mathrm{A}$ vector, and the resulting plasmids were used to transform the GS115 strain of P. pastoris. Postiviely transformed colonies were confirmed by PCR and evaluated for their recombinant protein expression levels on a small scale to ultimately select those with higher yields after 96 hours of induction with methanol. The purified recombinant proteins were homogenous, as visualized on SDS-PAGE gels with single bands of the expected weights: $35.5 \mathrm{kDa}$ for $\mathrm{HhXyl}$, corresponding to $33 \mathrm{kDa}$ of the recombinant enzyme and $2.5 \mathrm{kDa}$ of a six-histidine tail (Figure 2a), and $33 \mathrm{kDa}$ for XIP-I, corresponding to $29.5 \mathrm{kDa}$ of recombinant XIP-I and $2.5 \mathrm{kDa}$ of a six-histidine tail (Figure 2b).

Extracts from the digestive tracts of the borer showed hydrolytic activity on xylan polysaccharides isolated from wheat (data not shown). When the recombinant 


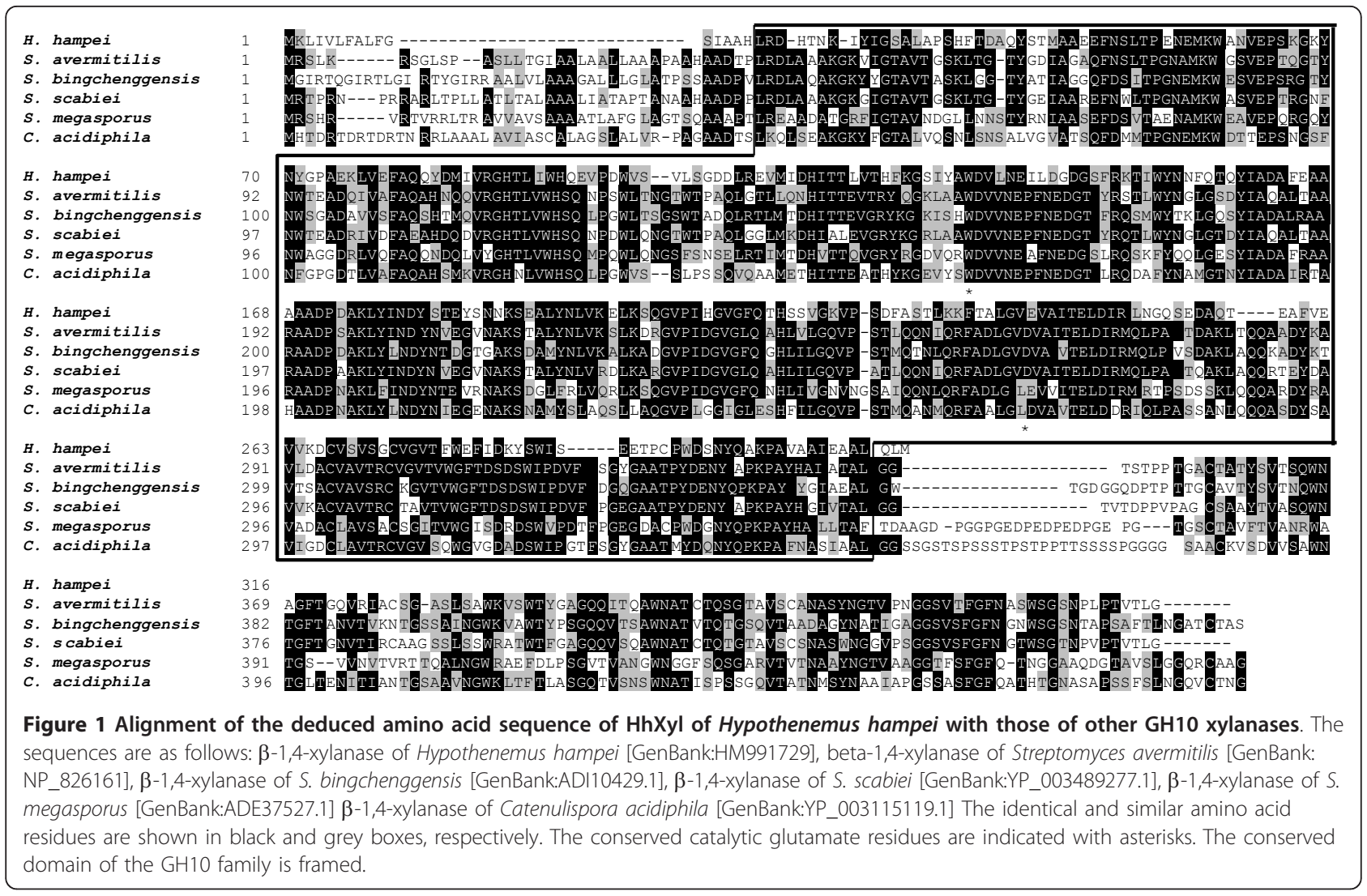

HhXyl enzyme was incubated with the xylan in solutions with a $\mathrm{pH}$ range between 3.0 and 8.0, maximum hydrolytic activity was observed at $\mathrm{pH}$ 5.5. Activity values greater than $80 \%$ of the maximal value were only detected at a pH between 5.8 and 6.0 (Figure 3a). This $\mathrm{pH}$ range is similar to that described for other reported xylanases [17]. Rapid hydrolysis was observed at $37^{\circ} \mathrm{C}$ (Figure $3 \mathrm{~b}$ ) but decreased with increasing temperature,

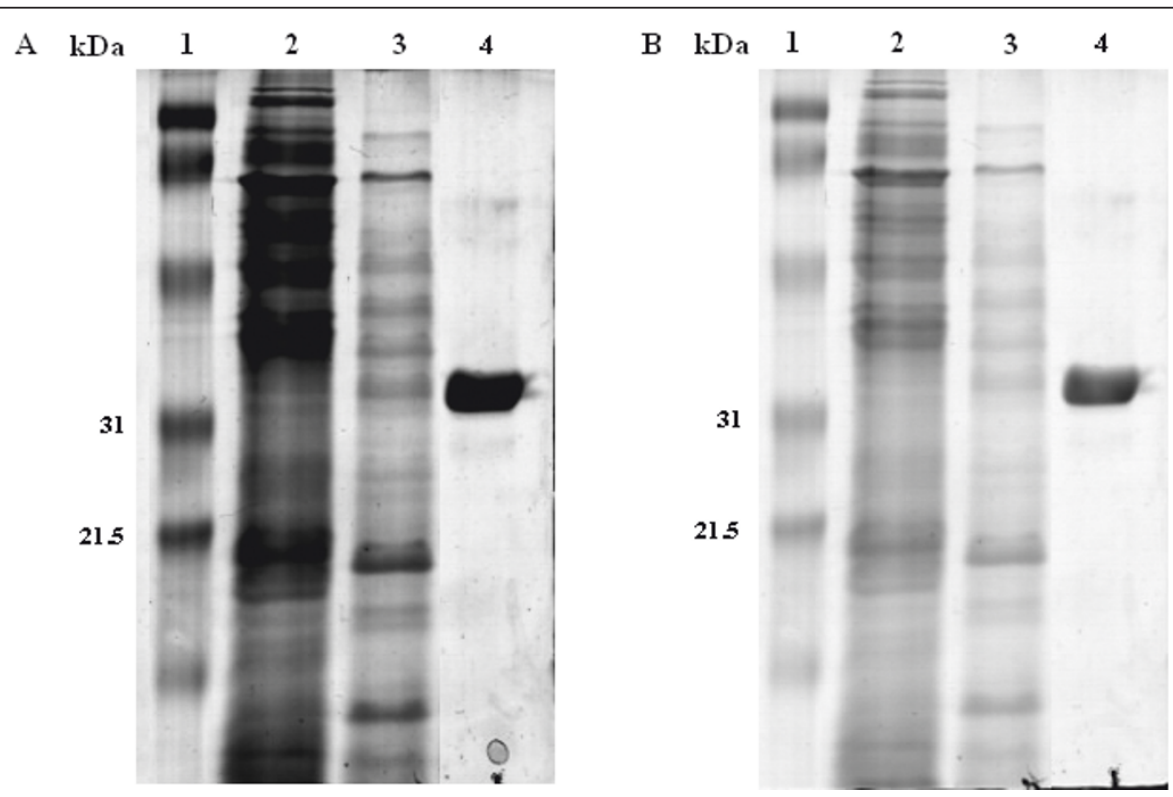

Figure 2 SDS-PAGE of the purified recombinant proteins. (A) HhXyl and (B) XIP-I from wheat. The proteins were purified by affinity chromatography using Ni-NTA resin. Lane 1: Low range weight marker (Bio-Rad), Lane 2: negative control for expression, Lane 3: Unpurified samples, Lane 4: $5 \mu$ l of the concentrated pure HhXyl (A) and XIP-I (B) proteins. The proteins were visualized with Coomassie brilliant blue R250. 

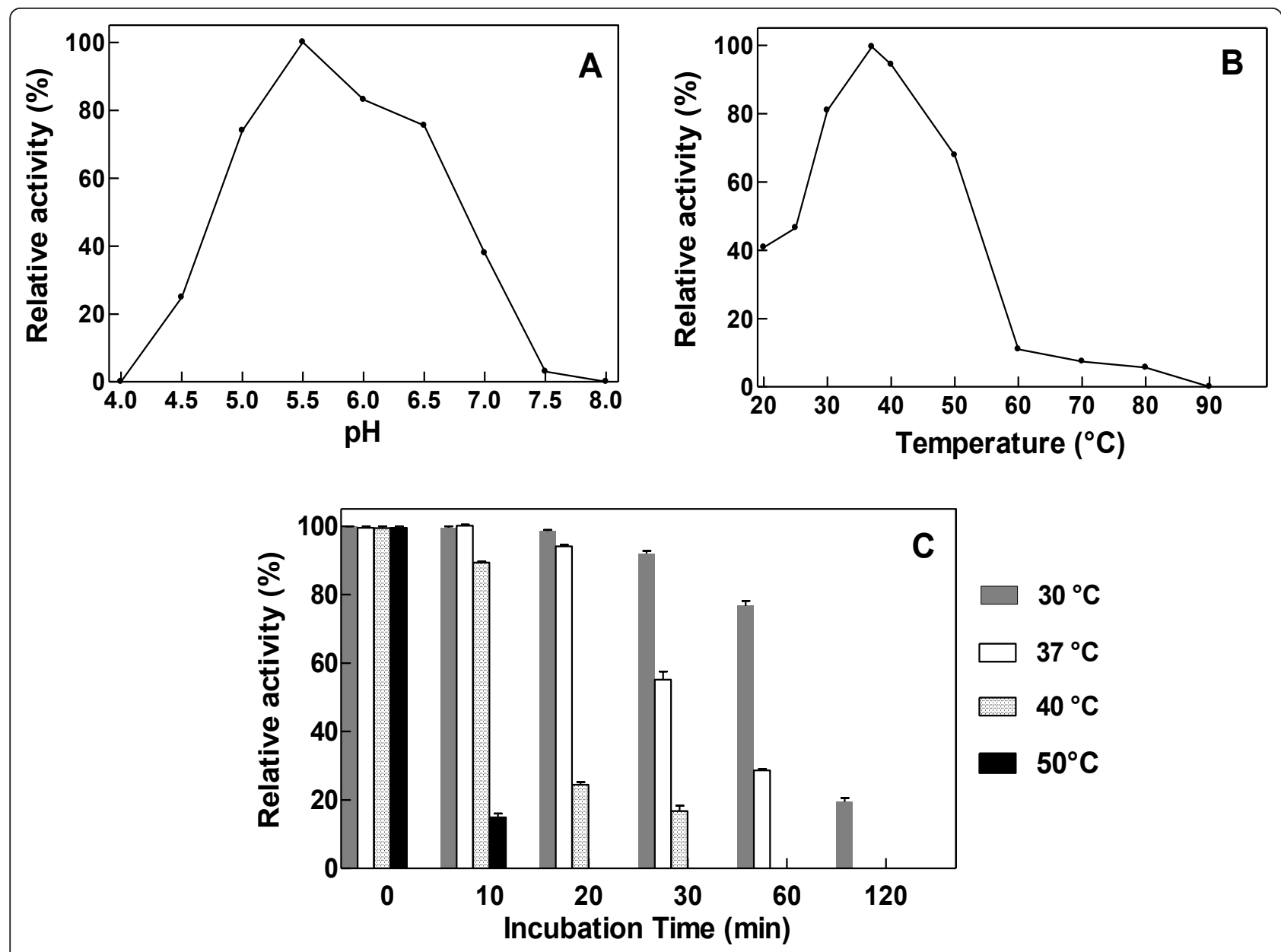

Figure 3 Characterization of recombinant HhXyl. (A) The effect of pH on the activity of HhXyL. (B) The effect of temperature on the activity of HhXyl. (C) The thermostability of HhXyl determined at different temperatures. The enzyme was incubated in the absence of of substrate for $10,20,30,60$ and 120 min before measuring its activity. Xylanase activity prior to pre-incubation was considered 100\%.

such that at $60^{\circ} \mathrm{C}$, activity was only $10 \%$ of the optimum level, and was $46 \%$ at room temperature $\left(25^{\circ} \mathrm{C}\right)$. These conditions are similar to those of the physiological environment in which the enzyme presumably acts: approximately $37^{\circ} \mathrm{C}$ and acid $\mathrm{pH}$ in the insect's digestive system. At its optimal temperature, HhXyl maintained $58 \%$ activity after a $30 \mathrm{~min}$ incubation. At higher temperatures, the activity of the enzyme decreased considerably after $10 \mathrm{~min}$ (Figure 3c). These parameters differed from those reported for other xylanases of fungal and bacterial origin, which are active and stable at temperatures between $50^{\circ} \mathrm{C}$ and $70^{\circ} \mathrm{C}$, and thus have the potential to be used on an industrial scale [18].

In addition, a zymogram analysis revealed that 2.5 and $5 \mu \mathrm{g}$ of pure HhXyl enzyme produces two clear bands, with a molecular weight of approximately $35 \mathrm{kDa}$, which corresponds to the observed HhXyl weight as determined by SDS-PAGE analysis. Congo red detection indicated that the enzyme has xylanase activity against xylan isolated from wheat (Figure 4).

\section{Effect of XIP-I on HhXyl}

The recombinant XIP-I was tested for potential inhibitory action on HhXyl. Varying amounts of purified recombinant XIP-I inhibited xylanase activity, and while the lowest amount evaluated $(2 \mu \mathrm{g})$ reduced activity by $50 \%, 8 \mu \mathrm{g}$ resulted in $100 \%$ inhibition. A similar inhibition occurred when the recombinant protein XIP-I was incubated with borer digestive tract extracts (Figure 5). The use of XIP-I therefore represents a potential candidate for generating resistance against the coffee berry borer. In biological assays using artificial diets including 30 or $60 \mu \mathrm{g}$ per well of XIP-I, $17 \%$ and $57 \%$ borer mortality rates, respectively, were observed after 12 days of ingestion (Figure 6). This mortality effect on $H$. hampei individuals on artificial diets supplemented with XIP-I 


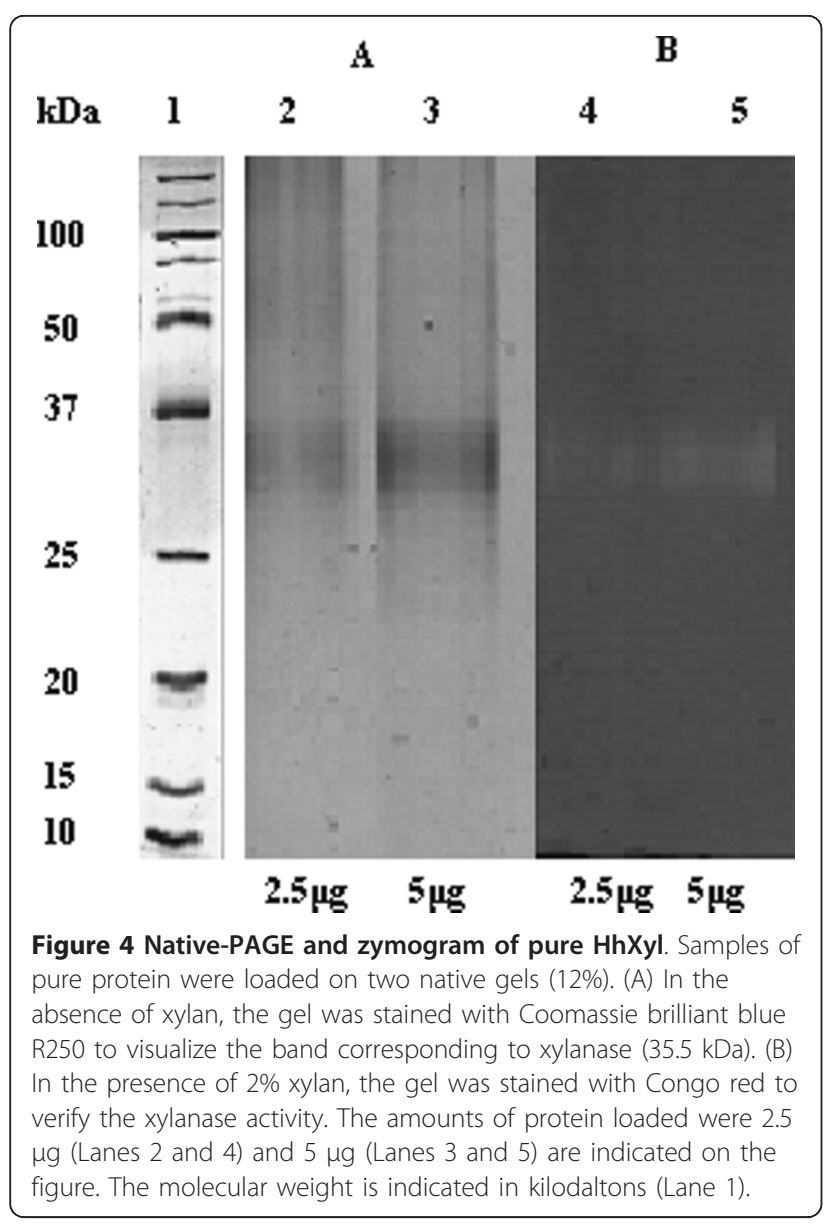

was likely caused by reduced hydrolysis of the primary cell wall xylan polysaccharides from coffee beans that were used as a source of nutrients. In in vitro studies, hydrolysis of insoluble fractions of coffee beans employing recombinant $\beta$-mannanase and $\beta$-xylanase enzymes from $H$. hampei, showed a synergistic effect since the reduction of these fractions is more efficient when both enzymes are present, than when is used alone (data not shown). The fact that xylanase promotes the reduction of these fractions when added mannanase suggests that the xylanase has a role in seed polymer degradation. Inhibiting the xylanase enzyme through the addition of XIP-I in the midgut of the insects could then lead to a deterioration of the catalytic ability of mannanase, which is the enzyme responsible for degrading galactomannans, the main polysaccharide in the coffee bean.

Vasconcelos et al (2011), reported the role of a xylanase inhibitor in the germination of spores of Phakopsora pachyrhizi. The effect was observed in bioassays in the absence of xylan in the reaction. This suggests that such inhibitors can have important biological effects in different processes in which other glycosyl hydrolases are involved, such as cellulases and mannanases [19]. Further analysis is required to elucidate the mechanism of action.

Another possible interpretation of these data is that XIP-I may inhibit glycosyl hydrolases other than xylanases and have consequent effects on the insect. Two plant proteins named XAIP and XAIP-II, with significant sequence identity and considerable structural similarity to XIP-I, have recently been shown to bind

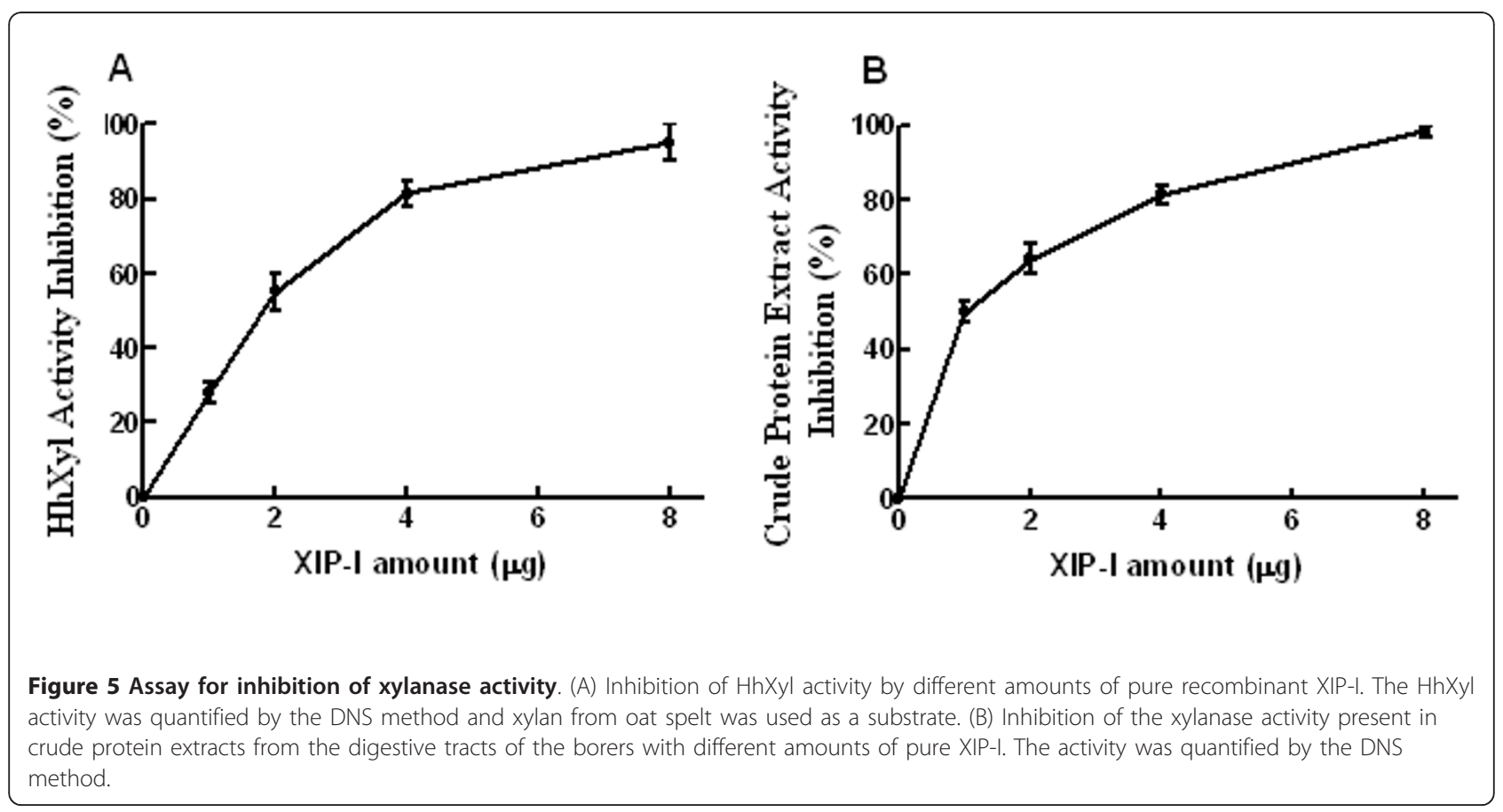




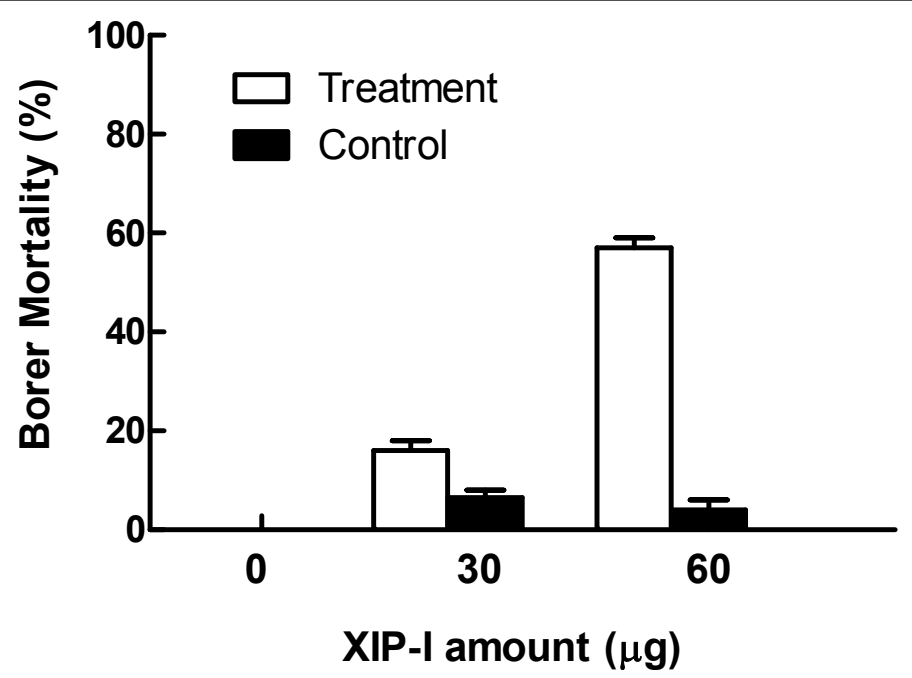

Figure 6 Biological effect of XIP-I in artificial diets. The corrected mortality rate of borer individuals due to their ingesting a Cenibroca diet supplementd with 30 and $60 \mu \mathrm{g}$ of XIP-I for 12 days compared to control insects.

specifically to two structurally very different hydrolases from different GH families (GH11 xylanase and GH13 $\alpha$-amylase), resulting in inhibition of enzymatic activities $[20,21]$.

XIP-I inhibits xylanases of the GH10 and GH11 families of fungal, but not bacterial origin in a reversible and competitive way. The exact nature of XIP-I biological activity is still unknown, although it is speculated to play an important role in plant defense against pathogens, and particularly those of fungal origin, because it lacks endogenous inhibitory activity against wheat xylanases $[9,10,22,23]$. Microbial GH enzymes are important for plant tissue invasion and degradation and so inhibitors of these enzymes are thought to play important roles in defense. It has been demonstrated that this type of inhibitor can be induced by pathogens as XIP-I is expressed strongly after inoculation with the fungus Erysiphe graminis and, in contrast to other inhibitors, XIP-I expression varies with the type of pathogen and the infected tissue [23].

\section{Conclusions}

In this study a functional xylanase gene $(H h X y l)$ from the digestive tracts of the coffee berry borer was cloned and expressed as a recombinant protein in a $P$. pastoris system. The enzyme has a predicted molecular mass of $34.92 \mathrm{kDa}$ and contains a putative domain conserved in GH10 proteins. The enzyme showed optimal activity in similar conditions to those of the physiological medium in the borer's digestive system and was able to effectively depolymerize xylan. The xylanase inhibitor, XIP-I, from wheat was shown to have inhibitory activity against both the recombinant HhXyl enzyme and crude protein extracts from borer digestive tracts. In addition, biological assays using XIP-I supplements to artificial diets induced mortality in borer individuals. Since xylan is not a quantitatively major component of coffee beans, two possible underlying mechanisms are suggested: i) XIP-I inhibition of xylanases may influence the action of other glycosyl hydrolases in the process of digesting the major coffee bean polysaccharides that constitute the diet of the insect. ii) XIP-I may inhibit other non-xylanase proteins that are important for insect metabolism, these results indicate that use of xylanase inhibitors may provide a strategy to reducing losses caused by the coffee berry borer.

\section{Methods}

Isolation and preservation of coffee berry borer digestive tracts

$H$. hampei larvae were grown in dry parchment coffee with a grain humidity of $45 \%$, at an average temperature of $27^{\circ} \mathrm{C}$ and $75 \%$ relative humidity in the dark. Prior to extracting the digestive tracts, larvae were incubated for $10 \mathrm{~min}$ at $4^{\circ} \mathrm{C}$ and then placed in a drop of phosphatebuffered saline (PBS), pH 7.2. For proteomic analysis, the tracts were stored in chilled PBS (pH 7.2) containing $5 \mathrm{mM}$ PMSF (phenylmethylsulfonyl fluoride). Tissues used for mRNA isolation were preserved in 0.1\% RNALater $^{\mathrm{TM}}$ (Qiagen, Valencia, CA, USA) at $-80^{\circ} \mathrm{C}$.

\section{Complementary DNA (cDNA) library}

Total RNA was extracted from $100 \mathrm{mg}$ of $H$. hampei larvae digestive tracts with the RNeasy ${ }^{\mathrm{TM}}$ kit (Qiagen, Valencia, CA, USA). mRNA was isolated using an Oligotex mRNA Mini Kit (Qiagen, Valencia, CA, USA), following the manufacturer's instructions. The directional cDNA library of the borer was created with the 
Creator ${ }^{\mathrm{TM}}$ SMART ${ }^{\mathrm{TM}}$ Library Construction Kit (Clontech, Mountain View, CA, USA). BLAST search of the GenBank database was performed using the processed cDNA sequences, which were compared to all available ESTs and genes (http://www.ncbi.nlm.nih.gov/blast). A BLASTX results with a bit scores greater than 80 and an E-values of less than $10^{-4}$ was regarded as a significant match.

\section{Amplification and cloning of the coffee berry borer xylanase gene and XIP-I}

The partial sequence of the borer xylanase gene $(H h X y l)$ was determined by amplifying genomic DNA with primers designed based on the sequences of putative xylanase genes identified in the cDNA library. The primers used for genome walking are listed in Table 1 . The complete sequence of the gene and the sequences of the regions adjacent to the 5' and 3' ends were obtained using a repeated genome walking technique and nested PCR protocols from the BD GenomeWalker ${ }^{\mathrm{TM}}$ Universal kit (Clontech, Mountain View, CA, USA). The fragments produced from the genome walk were cloned into the pGEM ${ }^{\circledR} \mathrm{T}$ easy vector (Promega, Madison, WI, USA). The sequence was analyzed with CodonCode Aligner software (V1.6.3), and homology was analyzed using BLASTX [24]. The XIP$I$ gene was amplified using genomic DNA from Soisson variety of wheat leaf tissue (Triticum aestivum), which had germinated for one week. The primers for amplification were as follows: XIP-I_Fw 5'-ATGGCGCCGCTCGCAGCCCG-3' and XIP-I_Rv 5'-GGCGTAGTACTTGATCAAGCTG-3', which were designed based on the registered gene sequence found in the Gemini database (http://www.ifr.ac.uk/Gemini/default.html). PCR was performed using the Advantage GC2 PCR system (Clontech, Mountain View, CA, USA) under the following conditions: $94^{\circ} \mathrm{C}$ for $3 \mathrm{~min} ; 35 \mathrm{cycles}$ of $94^{\circ} \mathrm{C}$ for $30 \mathrm{sec}$ and $68^{\circ} \mathrm{C}$ for 3 $\mathrm{min}$; and a final extension at $68^{\circ} \mathrm{C}$ for $10 \mathrm{~min}$. The 915-bp

Table 1 Primers used in genome walking PCR

\begin{tabular}{cc}
\hline Primers & Sequence (5'-3') $^{\prime}$ \\
\hline GSP1_XIL_GW1_3 & CCAATTCATGGAGTCGGTTTCCAATCTCAT \\
GSP1_XIL_GW1_5 & TTCGTTGAAGATTCGTTGACTACATCCCA \\
GSP2_XIL_GW1_3 & GTTGATGTGGCCATTACTGAATTGGACATC \\
GSP2_XIL_GW1_5 & GGCGTCCCATTTCATTCATTTCTGGTGT \\
GSP1_XIL_GW2_3 & GATTAAGCAATCCCGAATGATGTTCACAC \\
GSP1_XIL_GW2_5 & CCAAGTACTTTGGCCAGTAAACACGAAAA \\
GSP2_XIL_GW2_3 & CAAACAGTTACACGCCGGGGTAACTCCCAT \\
GSP2_XIL_GW2_5 & CACGGAAGCGTTTCGAGATATGAATG \\
GSP1_XIL_GW3_3 & CGGAATGCGATAGAAAGGGATGGTAAC \\
GSP1_XIL_GW3_5 & TCAAGTGTTCCCTATCAGGAATTGAC \\
GSP2_XIL_GW3_3 & GTCGTCATTTATAGTCTTCCCTGAAGTTG \\
GSP2_XIL_GW3_5 & CTAGTTCGTCAACTGCACAATGCCTGT \\
\hline
\end{tabular}

product was cloned into the GEM $^{\circledR}$ T-easy vector (Promega, Madison, WI, USA).

\section{Heterologous expression of the $P$. pastoris system}

The coding sequences for the endo-1,4- $\beta$-xylanase (HhXyl) and XIP-I proteins were cloned, without their respective signal sequences, into the pPICZ $\alpha \mathrm{A}$ vector (EasySelect $^{\mathrm{TM}}$ Pichia Expression Kit, Invitrogen) generating the constructs constructs pPICZ $\alpha \mathrm{A}-\mathrm{XIL}$ and pPICZ $\alpha$ A-XIP-I respectively. The $H h X y l$ gene was amplified with the forward primer XILHH_FW1_PIC 5'CCGCTCGAGAAAAGACACTTCAAAGACCATGCCAA-3' and the reverse primer XILHH_RV1_PIC 5'TGCTCTAGACCCATTAATTGCAAGGCAGCTT 3 'and the XIP I gene was amplified with the forward primer XIP1_FW_PIC 5'- CCGCTCGAGAAAAGAATGGCGCCGCTCGCAGCCCGGAG-3'and the reverse primer XIP1_RV_PIC 5'TGCTCTAGACCGGCGTAGTACTTGATCAAGCTG-3'. Forward primers contain the $X h o I$ restriction site (underlined) and reverse primers $\mathrm{XbaI}$. The PCR conditions were 10 cycles at $95^{\circ} \mathrm{C}$ for $1 \mathrm{~min}, 95^{\circ} \mathrm{C}$ for $25 \mathrm{sec}, 59^{\circ} \mathrm{C}$ for 45 sec and a final extension of $72^{\circ} \mathrm{C}$ for $30 \mathrm{sec}$ and 30 cycles of $95^{\circ} \mathrm{C}$ for $25 \mathrm{sec}, 56^{\circ} \mathrm{C}$ for $45 \mathrm{sec}, 72^{\circ} \mathrm{C}$ of $30 \mathrm{sec}$ and a final extension of $72^{\circ} \mathrm{C}$ for $10 \mathrm{~min}$, respectively. $E$. coli One Shot Top 10 cells (Invitrogen) were transformed with the constructs pPICZ $\alpha$ A-XIL and pPICZ $\alpha$ A-XIP-I. Positive clones were selected in LB media containing zeocin $(25 \mu \mathrm{g} / \mathrm{ml})$. The constructs were verified by restriction pattern analysis and sequencing. The GS115 strain of $P$. pastoris was transformed by electroporation at $2.0 \mathrm{kV}, 25 \mu \mathrm{F}$ and $200 \Omega$ using $5 \mu \mathrm{g}$ of recombinant plasmids that were linearized with SacI. After three days of growth ak $30^{\circ} \mathrm{C}$, the positive colonies were selected on YPDS plates (1\% yeast extract, $2 \%$ peptone, $2 \%$ dextrose, $1 \mathrm{M}$ sorbitol, $2 \%$ agar and $100 \mathrm{mg} / \mathrm{L}$ zeocin). Integration of the $H h X y l$ and XIP-I genes into the $P$. pastoris genome was confirmed by PCR using the AOX1 forward (5'-GACTGGTTCCAATTGACAAGC3') and AOX1 reverse primers (5'-GCAAATGGCATTCTGACATCC-3').

Transformed $P$. pastoris cells were inoculated into 10 $\mathrm{ml}$ of buffered minimal glycerol complex media BMGY (1\% yeast extract, $2 \%$ peptone, $100 \mathrm{mM}$ potassium phosphate buffer [pH 6.0], 1.34\% yeast nitrogen base (YNB), $0.0004 \%$ of biotin and $1 \%(\mathrm{v} / \mathrm{v})$ glycerol) at $30^{\circ} \mathrm{C}$ and were shaken $250 \mathrm{rpm}$, until an $\mathrm{OD}_{600}$ between 3.0 and 6.0 was achieved. To induce HhXyl and XIP-I production, $P$. pastoris cell pellets were grown in BMMY (1\% yeast extract, $2 \%$ peptone, $100 \mathrm{mM}$ potassium phosphate buffer [pH 6.0], 1.34\% YNB, $0.0004 \%$ biotin and $0.5 \%$ methanol) using $1 / 5$ of the original culture media (10 $\mathrm{ml})$. The cultures were incubated at $30^{\circ} \mathrm{C}$ and with shaking at $250 \mathrm{rpm}$. Absolute methanol was added to a final 
concentration of $0.5 \%$ every 24 hours for 5 days. The expression of the secreted proteins was evaluated by SDS-PAGE.

\section{Purification of the recombinant proteins}

The recombinant proteins expressed in $P$. pastoris were purified by affinity chromatography using Ni-NTA resin (Qiagen, Valencia, CA, USA). The proteins that bound to the resin due to their tag of six-histidines $\mathrm{N}$-terminal tag end were eluted with imidazole $(500 \mathrm{mM})$. The eluate fractions were concentrated by ultrafiltration using an Amicon ultra-0.5, $3 \mathrm{kDa}{ }^{\circledR}$ centrifugal filter (Millipore, Bedford, MA) and the concentrated samples were analyzed by SDS-PAGE. Protein concentrations were determined using the Bradford method and bovine serum albumin was used as a standard [25].

\section{Enzymatic activity assay}

A total of $10 \mu \mathrm{l}$ of $\mathrm{HhXyl}(0.5 \mu \mathrm{g} / \mu \mathrm{l})$ was added to 490 $\mu \mathrm{l}$ of $200 \mathrm{mM}$ of acetate buffer, $\mathrm{pH} 5.0$, containing 4\% $(\mathrm{w} / \mathrm{v})$ xylan (Sigma X0627). In addition, $10 \mu \mathrm{l}$ of the digestive tracts extracts $(0.5 \mu \mathrm{g} / \mu \mathrm{l})$ was evaluated for xylanase activity. After incubation at $37^{\circ} \mathrm{C}$ for 1 hour, the amount of reduced sugars released by the reactions was quantified by the 3,5-dinitrosalicylic (DNS) method. For each $100 \mu \mathrm{l}$ of reaction mixture, $100 \mu \mathrm{l}$ of the Bernfeld reagent was added. The mixture was heated to boiling point, was boiled for $5 \mathrm{~min}$, and the absorbance was measured at $540 \mathrm{~nm}$. Xylose was used as a standard [26]. One unit of xylanase activity is defined as the amount of enzyme releasing $1 \mu$ mole of xylose equivalents per minute. All measurements were performed in triplicate.

\section{The effects of $\mathrm{pH}$ and temperature on enzymatic activity}

To evaluate the effect of $\mathrm{pH}$ on xylanase activity, $4 \%(\mathrm{w} /$ v) xylan from oat spelts (Sigma-Aldrich, St. Louis, MO, USA) were prepared in acetate buffer ( $\mathrm{pH} 3.0$ to 5.0) and phosphate buffer ( $\mathrm{pH} 6.0$ to 8.0). Each substrate solution was incubated with $10 \mu \mathrm{l} \mathrm{HhXyl}$ solution $(0.5$ $\mu \mathrm{g} / \mu \mathrm{l})$ at $37^{\circ} \mathrm{C}$ for one hour. To evaluate the effect of temperature, the activity assay was performed at $\mathrm{pH} 5.5$ and at temperature ranging from 20 to $90^{\circ} \mathrm{C}$. The thermostability of the enzyme was determined by measuring xylanase activity at $37^{\circ} \mathrm{C}$ for one hour after preincubating the enzyme for $10,20,30,60$ or $120 \mathrm{~min}$ at $30^{\circ} \mathrm{C}$, $37^{\circ} \mathrm{C}, 40^{\circ} \mathrm{C}$ or $50^{\circ} \mathrm{C}$. The xylanase activity measured prior to the preincubation at the different temperatures was considered to be $100 \%$.

\section{Zymogram analysis of xylanase activity}

Aliquots $(2.5$ and $5 \mu \mathrm{g})$ of HhXyl enzyme were analyzed by native PAGE (12\%), according to the method described by Laemmli [27]. The protein bands were visualized with Coomassie stain. For the zymogram analysis, $2 \%(\mathrm{w} / \mathrm{v})$ xylan was incorporated into the gel and electrophoresis was performed at $4^{\circ} \mathrm{C}$. To evaluate the xylanase activity, the gel was incubated at $\mathrm{pH} 5.0$ for one hour at $37^{\circ} \mathrm{C}$. The enzymatic activity was visualized by incubating the gel in Congo red dye $(0.25 \%)$ for 15 min, followed by successive washes with $1 \mathrm{M} \mathrm{NaCl}$. To intensify the color, the gel was placed in 5\% acetic acid.

\section{The effect of XIP-I protein on xylanase enzymatic activity} Crude protein extracts from the digestive tracts of L2 larvae and recombinant enzyme HhXyl (5 $\mu$ g each one) were incubated separately for $30 \mathrm{~min}$ at $37^{\circ} \mathrm{C}$ with three amounts of purified recombinant XIP-I (2, 4 and $8 \mu \mathrm{g})$. Subsequently, $4 \%$ xylan was added to the reactions, and the samples were incubated for one additional hour. The percentage of XIP-I induced inhibition relative to the negative control (no inhibitor) was calculated according to equation (1):

$\%$ inhibition $=100-\left(\mathrm{OD}_{540}\right.$ reaction with inhibitor $* 100 / \mathrm{OD}_{540}$ reaction without inhibitor $)$

\section{Bioassays}

The biological effects of XIP-I on the coffee berry borer were evaluated by providing the insects with a Cenibroca artificial diet [28], that was enriched with the recombinant XIP-I protein. Multiwell plates were used to provide $2 \mathrm{ml}$ of food that was supplemented with 30 or $60 \mu \mathrm{g}$ of XIP-I protein or distilled water. The borer eggs were extracted from the parchment coffee beans that were infested for 10 days, and 20 eggs were placed in each well until hatching. During the first instar larval stage (L1), a drop of the XIP-I solution or distilled water (control) was applied to the preoral cavity of each larva. The diet was maintained under controlled conditions at $27^{\circ} \mathrm{C}$ and $75 \%$ humidity. Each evaluation was performed in duplicate. The development of the larvae was followed daily until they reached the pupal stage when the effect of the diet on their mortality was evaluated. The mortality rate was calculated and was corrected relative to the control in accordance with Abbott's formula [29].

\section{Acknowledgements}

This work was supported by the Ministry of Agriculture and Rural Development of Colombia and National Federation of Coffee Growers of Colombia (contract \# 074/2007), the authors thank the Bioinformatics Unit of CENICAFÉ for its contributions to the sequence analysis and Jocelyn Rose from Department of Plant Biology, Cornell University for reviewing the manuscript and for his valuable contributions.

\section{Author details}

'Disciplina de Mejoramiento Genético, Centro Nacional de Investigaciones de Café (CENICAFE), Planalto, Km 4 vía antigua Chinchiná-Manizales, Chinchiná, Colombia. ${ }^{2}$ Disciplina de Fisiología Vegetal; Centro Nacional de 
Investigaciones de Café (CENICAFE), Planalto, Km 4 vía antigua ChinchináManizales, Chinchiná, Colombia.

\section{Authors' contributions}

JRG: Performed the isolation and preservation of the coffee berry borer digestive tracts. BPH and CFR: Constructed the borer CDNA library, performed the identification, amplification and cloning of HhXYl and XIP-I, as well as the subcloning in a Pichia vector and expression. ARS: participated in the procedures of induction of expression of the recombinant proteins. CAG, $\mathrm{BPH}$ and JMO: purification and characterization of HhXyl. CAG and BPH: Performed the HhXy enzymatic assays, the inhibition assays, and the bioassays. BPH, CAG and JMO: drafted the manuscript. RAZ: Conceived the study and participated in its design and coordination and helped draft the manuscript.

All authors read and approved the final version of this manuscript.

\section{Competing interests}

The authors declare that they have no competing interests.

Received: 6 October 2011 Accepted: 10 January 2012

Published: 10 January 2012

\section{References}

1. Pava-Ripoll M, Posada FJ, Momen B, Wang C, St. Leger R: Increased pathogenicity against coffee berry borer, Hypothenemus hampei (Coleoptera: Curculionidae) by Metarhizium anisopliae expressing the scorpion toxin (AaIT) gene. Journal of Invertebrate Pathology 2008, 99(2):220-226.

2. Bustillo A: Features of the coffee berry borer, Hypothenemus hampei en Colombia. In insects and their management in Colombia coffee growing. Edited by: Bustillo AE. Chinchina, Caldas; 2008:466.

3. Bradbury AGW, Halliday DJ: Chemical structures of green coffee bean polysaccharides. Journal of Agricultural and Food Chemistry 1990, 38(2):389-392.

4. Redgwell R, Fischer M: Coffee carbohydrates. Braz J Plant Physiol 2006, 18(1):9.

5. Roy I, Gupta A, Khare SK, Bisaria VS, Gupta MN: Immobilization of xylandegrading enzymes from Melanocarpus albomyces IIS 68 on the smart polymer Eudragit L-100. Applied Microbiology and Biotechnology 2003, 61(4):309-313.

6. Wakiyama M, Tanaka H, Yoshihara K, Hayashi S, Ohta K: Purification and properties of family-10 endo-1,4-[beta]-xylanase from Penicillium citrinum and structural organization of encoding gene. Journal of Bioscience and Bioengineering 2008, 105(4):367-374

7. Techapun C, Poosaran N, Watanabe M, Sasaki K: Thermostable and alkaline-tolerant microbial cellulase-free xylanases produced from agricultural wastes and the properties required for use in pulp bleaching bioprocesses: a review. Process Biochemistry 2003, 38(9):1327-1340.

8. Polizeli MLTM, Rizzatti ACS, Monti R, Terenzi HF, Jorge JA, Amorim DS: Xylanases from fungi: properties and industrial applications. Applied Microbiology and Biotechnology 2005, 67(5):577-591.

9. Beliën T, Van Campenhout S, Robben J, Volckaert G: Microbial Endoxylanases: Effective Weapons to Breach the Plant Cell-Wall Barrier or, Rather, Triggers of Plant Defense Systems? Molecular Plant-Microbe Interactions 2006, 19(10):1072-1081.

10. McLauchlan WR, Garcia-Conesa MT, Williamson G, Roza M, Ravestein P, Maat J: A novel class of protein from wheat which inhibits xylanases. The Biochemical journal 1999, 338(Pt 2):441-446.

11. Payan F, Leone P, Porciero S, Furniss C, Tahir T, Williamson G, Durand A Manzanares P, Gilbert HJ, Juge N, et al: The Dual Nature of the Wheat Xylanase Protein Inhibitor XIP-I. Journal of Biological Chemistry 2004, 279(34):36029-36037.

12. Sancho Al, Faulds CB, Svensson B, Bartolomé B, Williamson G, Juge N: Cross-inhibitory activity of cereal protein inhibitors against a-amylases and xylanases. Biochimica et Biophysica Acta (BBA) - Proteins \&amp; Proteomics 2003, 1650(1-2):136-144.

13. Bendtsen JD, Nielsen $H$, von Heijne $G$, Brunak S: Improved prediction of signal peptides: SignalP 3.0. J Mol Biol 2004, 340(4):783-795.
14. Subramaniyan S, Prema P: Biotechnology of Microbial Xylanases: Enzymology, Molecular Biology, and Application. Critical Reviews in Biotechnology 2002, 22(1):33-64.

15. Biely P, Vrsanska M, Tenkanen M, Kluepfel D: Endo-beta-1,4-xylanase families: differences in catalytic properties. J Biotechnol 1997, 57(13):151-166

16. Rye CS, Withers SG: Glycosidase mechanisms. Current Opinion in Chemical Biology 2000, 4(5):573-580.

17. Wang $Y$, Zhang $H$, He $Y$, Luo $H$, Yao B: Characterization, gene cloning, and expression of a novel xylanase XYNB from Streptomyces olivaceoviridis A1. Aquaculture 2007, 267(1-4):328-334.

18. Chantasingh D, Pootanakit $K$, Champreda V, Kanokratana P, Eurwilaichitr L: Cloning, expression, and characterization of a xylanase 10 from Aspergillus terreus (BCC129) in Pichia pastoris. Protein Expression and Purification 2006, 46(1):143-149.

19. Vasconcelos E, Santana C, Godoy C, Seixas C, Silva M, Moreira L, OliveiraNeto $O$, Price D, Fitches E, Filho $E$, et al: A new chitinase-like xylanase inhibitor protein (XIP) from coffee (Coffea arabica) affects Soybean Asian rust (Phakopsora pachyrhizi) spore germination. BMC Biotechnology 2011, 11(1):14.

20. Kumar S, Singh N, Sinha M, Dube D, Singh SB, Bhushan A, Kaur $P$, Srinivasan A, Sharma S, Singh TP: Crystal structure determination and inhibition studies of a novel xylanase and a-amylase inhibitor protein (XAIP) from Scadoxus multiflorus. FEBS Journal 2010, 277(13):2868-2882.

21. Kumar S, Singh N, Mishra B, Dube D, Sinha M, Singh SB, Dey S, Kaur $P$, Sharma S, Singh T: Modulation of inhibitory activity of xylanase - alphaamylase inhibitor protein (XAIP): binding studies and crystal structure determination of XAIP- II from Scadoxus multiflorus at $1.2 \mathrm{~A}$ resolution. BMC Structural Biology 2010, 10(1):41.

22. Elliott GO, Hughes RK, Juge N, Kroon PA, Williamson G: Functional identification of the cDNA coding for a wheat endo-1,4- $\beta-D$-xylanase inhibitor 11 The XIP-I sequence has been submitted to the EMBL database under accession number AJ422119. FEBS letters 2002, 519(1):66-70.

23. Igawa T, Tokai T, Kudo T, Yamaguchi I, Kimura M: A Wheat Xylanase Inhibitor Gene, Xip-I, but Not Taxi-I, Is Significantly Induced by Biotic and Abiotic Signals That Trigger Plant Defense. Bioscience, Biotechnology, and Biochemistry 2005, 69(5):1058-1063.

24. Altschul SF, Madden TL, Schaffer AA, Zhang J, Zhang Z, Miller W, Lipman DJ: Gapped BLAST and PSI-BLAST: a new generation of protein database search programs. Nucleic Acids Res 1997, 25(17):3389-3402.

25. Bradford MM: A rapid and sensitive method for the quantitation of microgram quantities of protein utilizing the principle of protein-dye binding. Analytical Biochemistry 1976, 72(1-2):248-254.

26. Bernfeld P: [17] Amylases, $a$ and $\beta$. In Methods in Enzymology. Volume 1. Academic Press; 1955:149-158.

27. Laemmli UK: Cleavage of Structural Proteins during the Assembly of the Head of Bacteriophage T4. Nature 1970, 227(5259):680-685.

28. Portilla RM: Development and evaluation of and artificial diet for breeding Hypothenemus hampei. Revista Cenicafé 1999, 50(1):14.

29. Abbott WS: A method of computing the effectiveness of an insecticide. 1925. J Am Mosa Control Assoc 1987, 3(2):302-303.

doi:10.1186/1756-0500-5-23

Cite this article as: Padilla-Hurtado et al:: Cloning and expression of an endo-1,4- $\beta$-xylanase from the coffee berry borer, Hypothenemus hampei. BMC Research Notes 2012 5:23. 